\title{
MENINGKATKAN KUALITAS PEMBELAJARAN DENGAN MENGOPTIMALKAN PENGGUNAAN ALAT PERAGA MATEMATIKA (SUATU UPAYA MEMBANGUN DAN MENGEMBANGKAN KREATIVITAS)
}

\author{
Bahar1), Fitriani2) \\ ${ }^{1}$ Dosen Jurusan Pendidikan Matematika FMIPA UNM \\ Kampus: Jalan Mallengkeri Raya, Parang Tambung, Makassar, 90224 \\ 2Fakultas Tarbiyah dan Ilmu Keguruan UIN Alauddin Makassar \\ Kampus II: Jalan H. M. Yasin Limpo Nomor 36 Samata-Gowa \\ E-mail: bhrfitriani@gmail.com¹), fitriani_b@yahoo.com²)
}

\begin{abstract}
Abstrak:
Penelitian ini bertujuan untuk mengatasi permasalahan di atas yakni dengan menggunakan alat peraga yang didesain oleh penulis sendiri. Ada pun alat peraga tersebut terdiri dari: bangun datar (segitiga, segiempat, segibanyak, lingkaran) dan bangun ruang (kubus, prisma, tabung, limas, kerucut, bola). Untuk pelaksanaan penelitian digunakan metode demonstrasi yaitu memeragakan alat-alat yang sudah didesain untuk menjelaskan konsep-konsep geometri yaitu tentang luas pada bangun datar, luas penampang dan volume bangun ruang. Hasil penelitian menunjukkan peningkatan hasil belajar hal ini dapat dilihat dari skor rata-rata nilai rata-rata yang dicapai siswa pada awal siklus 1 kategori rendah $(5,00)$ sedangkan pada akhir siklus 1 nilai rata-rata siswa dalam kategori sedang $(6,19)$, sedangkan pada akhir siklus 2 nilai rata-rata dalam kategori tinggi $(7,50)$, dan pada akhir siklus 3 nilai ratarata dalam kategori sangat tinggi $(8,00)$ hasil belajar siswa .
\end{abstract}

Kata Kunci: Geometri, Bangun Datar, Bangun Ruang

$\mathrm{M}$ atematika mempunyai objek abstrak berupa fakta abstrak, konsep abstrak, operasi abstrak serta prinsip abstrak. Untuk menyiasati tingkat abstraksi objek-objek matematika, berdasarkan pengalaman dan usulan guru sebagai tenaga pendidik, solusi yang dikemukakan adalah harus diusahakan memilih dan memberikan pelajaran yang tepat kepada siswa, mereka berpendapat bahwa alat peraga adalah alternatif yang relevan dan handal khususnya untuk tingkat pendidikan dasar dan menengah. Suatu ide abstrak yang dapat disajikan dalam dunia nyata, memberikan pemahaman tentang konsep yang lebih tepat. Cara belajar dengan menggunakan benda konkret adalah belajar yang diperoleh melalui pengalaman, melihat, mengamati dan mengenal sifat-sifat dari objek itu.

Berdasarkan laporan guru, bahwa tidak semua pokok bahasan yang ada pada mata pelajaran matematika, pada Sekolah Lanjutan Tingkat Pertama 
dapat dipahami dengan baik oleh siswa pada saat diajarkan. Hal ini mungkin disebabkan materi atau pokok bahasan tersebut tingkat abstraksinya terlalu tinggi, sehingga dipikirkan oleh guru untuk menggunakan media tertentu untuk mengurangi tingkat abstraksi materi tersebut. Untuk itu, matematika sebagai ilmu dasar yang diajarkan di semua jenjang pendidikan sejauh mungkin disesuaikan dengan perkembangan kognitif peserta didik.

Selanjutnya telah dialami oleh para guru, adanya kenyataan bahwa akan ditemukan kesulitan menuangkan ilmu pengetahuan sebanyakbanyaknya kepada peserta didik, meskipun para guru sangat terbatas dalam menggunakan perangkat pembelajaran. Untuk itu, sangat diharapkan bagi guru untuk menguasai bagian-bagian dari keterampilan proses, seperti: mengamati, menafsirkan pengamatan, meramalkan, menerapkan konsepkonsep, merancang/menggunakan alat peraga, merencanakan penelitian, berkomunikasi dan mengajukan pertanyaan.

Bagian-bagian keterampilan proses yang disebut di atas terkait satu sama lainnya, sehingga diperlukan upaya mengembangkan suatu konsep matematika dengan menggunakan alat peraga matematika agar peserta didik mudah memahami konsep tersebut. Selain itu, penelitian ini juga bertujuan untuk mengatasi permasalahan di atas yakni dengan menggunakan alat peraga yang didesain oleh penulis sendiri.

\section{HASIL BELAJAR}

Untuk meningkatkan hasil belajar siswa, maka seyogianya guru merencanakan suatu bentuk pembelajaran yang dapat memotivasi siswa untuk belajar matematika. Salah satu alternatif adalah guru dapat merancang (membuat dan menggunakan) alat peraga yang dapat mempermudah penanaman suatu konsep matematika di sekolah. Pada jenjang pendidikan Sekolah Lanjutan Tingkat Pertama (SLTP), matematika sebagai bahan pelajaran adalah bagian-bagian matematika yang dipilih berdasar atau berorientasi kepada (1) makna pendidikan, yaitu untuk mengembangkan kemampuan berpikir dan kepribadian peserta didik, dan (2) tuntutan perkembangan yang nyata dari lingkungan masyarakat yang seiring dengan perkembangan ilmu dan teknologi.

Berkaitan dengan tuntutan dan aspirasi dari lingkungan masyarakat, yang mensinyalir kurangnya pengetahuan para guru tentang bagaimana merancang dan menggunakan alat peraga dalam mengajarkan matematika, maka dianggap perlu melakukan orientasi yang mendasar sebagai berikut: 


\section{a. Peningkatan Sumber Daya Manusia}

Guru sebagai salah satu penentu kualitas sumber daya manusia seharusnya memperoleh perioritas utama dalam upaya pengembangan kemampuan profesionalnya. Ilmu yang mereka miliki akan ditransfer kepada siswanya dengan berbagai cara yang mereka ketahui. Oleh karena itu, seorang guru harus profesional dalam bidangnya. Untuk mencapai hal ini, salah satu cara yang paling efekif untuk dilakukan adalah dengan jalan melatih mereka untuk membuat dan menggunakan alat peraga, utamanya pada penerapan konsep yang sifatnya sangat abstrak. Masalah yang mereka hadapi harus dapat dipecahkan dengan cara mereka sendiri, sebab merekalah yang paling mengetahui tentang masalah yang sering muncul dalam kelas.

Guru yang tidak mempunyai pengetahuan tentang bagaimana cara mengajarkan konsep yang sifatnya abstrak, akan mengalami kesulitan dan ia tidak ingin tahu penyebab masalah yang muncul di kelas mereka. Sebaliknya jika mereka mengetahui tentang bagaimana teknik mengajar dengan menggunakan alat peraga tertentu, maka guru yang bersangkutan setiap saat akan selalu termotivasi mencari penyebab dari masalah yang timbul dalam proses belajar mengajar.

b. Peningkatan Kemampuan Profesional

Kemampuan profesional seorang guru SLTP hanya mungkin tercapai dengan maksimal, jika guru tersebut sudah tahu tentang bagaimana merancang, membuat, dan menggunakan alat peraga, utamanya alat peraga mengajar, penggunaan media belajar, dan teknik pendekatan yang tepat antara guru dan peserta didik, tidak selamanya dapat dilaksanakan dengan mudah. Akan tetapi membutuhkan suatu proses yang dapat memberikan alternatif terbaik di antara semua rencana yang ada. Dalam hal ini salah satu cara yang paling efektif untuk menjawab masalah tersebut adalah dengan jalan merancang teknik penggunaan alat peraga pembelajaran, walaupun sifatnya hanya terbatas pada satu kelas dimana guru tersebut mengajar.

c. Pembelajaran Matematika dengan Alat Peraga

Untuk meningkatkan motivasi kerja para guru SLTP, maka pengetahuan pembuatan dan penggunaan alat peraga selayaknya dimiliki oleh seorang guru. Guru yang mempunyai pengetahuan tentang hal tersebut akan mengetahui penyebab mengenai kelancaran maupun hambatan proses belajar mengajar. Dengan demikian motivasi untuk belajar akan semakin tinggi. Lebih jauh dari itu, guru yang mengetahui teknik mengajar dengan menggunakan alat peraga matematika, akan selalu berpikir bagaimana 
meningkatkan "mutu pendidikan" matematika melalui penggunaan alat peraga yang relevan dengan pokok-pokok bahasan yang ada dalam pelajaran matematika terutama dalam bidang geometri.

Temuan-temuan baru yang diperoleh melalui pelatihan membuat dan menggunakan alat peraga ini, akan membangkitkan minat dan motivasi guru untuk bekerja atau mengajar lebih giat guna menindaklanjuti temuan tersebut. Sebaliknya, mereka yang kurang pengetahuannya tentang hal tersebut akan bermasa bodoh dan kurang berminat untuk mengembangkan pengetahuannya. Guru jarang memikirkan bagaimana meningkatkan mutu pendidikan, sebab tidak memiliki sarana dan pengetahuan yang memadai dalam pembuatan dan penggunaan alat peraga matematika.

Upaya penurunan derajat keabstrakan objek-objek matematika dalam proses pembelajaran perlu dilakukan melalui pendekatan dengan menggunakan alat peraga, mengingat sasaran pembelajaran matematika sebagai bahan pelajaran merupakan ransangan yang datang dari luar diri peserta didik. Ransangan tersebut akan menimbulkan tegangan-tegangan psikologis pada diri peserta didik. Karena itu, pesrta didik perlu belajar mempergunakan cara-cara baru dalam mereduksinya. Cara mereduksi tegangan psikologis yang timbul dalam diri peserta didik adalah menyusun matematika secara induktif dan kemudian beberapa saat berikutnya digunakan pendekatan deduktif (Arifin, 1991).

Salah satu peranan alat peraga dalam pembelajaran matematika adalah meletakkan ide-ide dasar konsep.dengan bantuan alat peraga yang sesuai, siswa dapat memahami ide-ide dasar yang mendasari sebuah konsep, menetahui cara membuktikan suatu rumus atau teorema, dan dapat menarik suatu kesimpulan dari hasil pengamatannya. Setelah siswa mendapat kesempatan terlibat dalam proses pengamatan dengan bantuan alat peraga, maka dapat diharapkan akan tumbuh minat belajar matematika pada dirinya, dan akan menyenangi konsep yang disajikan, karena sesuai dengan tahap perkembangan mentalnya yang masih menyenangi permainan. Alat peraga dapat pula membantu siswa untuk berpikir logis dan sistimatis, sehingga mereka pada akhirnya memiliki pola pikir yang dioerlukan dalam mempelajari matematika (Barnes, 1996).

Alat peraga pembelajaran, teacing aids, atau audiovisual aids (AVA) adalah alat yang digunakan guru ketika mengajar untuk membantu memperjelas materi pembelajaran yang disampaikan kepada siswa dan mencegah terjadinya verbalisme pada diri siswa. Pembelajaran yang 
sebaliknya pembelajaran akan lebih menarik bila siswa gembira belajar atau senang karena mereka merasa tertarik dan mengerti pelajaran yang diterimanya.

Belajar yang efektif harus mulai dengan pengalaman langsung atau pengalaman konkret dan menuju kepada pengalaman yang lebih abstrak. Belajar akan lebih efektif jika dibantu dengan alat peraga pembelajaran dari pada bila siswa belajar tanpa dibantu dengan alat peraga pembelajaran (Hudoyo, 1990).

\section{METODE PENELITIAN}

Penelitian ini adalah penelitian tindakan berbasis kelas yang berlokasi di SLTP Negeri 26 Makassar. Sekolah ini adalah salah satu sekolah mitra UNM Makassar yang setiap tahun menjadi tempat PPL mahasiswa UNM Makassar. Di sekolah ini dipilih dua guru matematika yang menjadi subjek sekaligus objek penelitian ini, dengan demikian hasil yang diperoleh atau keluaran yang dihasilkan dalam penelitian ini, diharapkan besar manfaatnya untuk perbaikan PPL bidang studi matematika.

Berdasarkan dari gagasan guru, maka cara pemecahan masalah yang ditawarkan adalah:

a. Membuat/mendesain/meredesain alat peraga untuk setiap materi pelajaran (pokok bahasan) matematika.

b. Memodifikasi/merekayasa bentuk alat peraga yang telah ada, agar lebih sesuai/handal dalam mengurangi tingkat abstraksi materi pelajaran.

c. Melaksanakan peningkatan intensitas penggunaan alat peraga matematika.

d. Meningkatkan kemampuan guru dalam membuat dan menggunakan alat peraga dengan memperkuat kolaborasi yakni berdiskusi dan bekerja bersama dalam merancang alat peraga.

e. Dalam melaksanakan poin a-d, sedapat mungkin merancang (membuat dan menggunakan) alat peraga yang bahannya atau bendanya mudah didapat dan ada di sekitar tempat proses belajar mengajar, lebih jauh diusahakan agar mudah disimpan dan dapat digunakan berkali-kali (tahan lama).

Langkah selanjutnya yang dilakukan adalah melakukan diskusi intensif teman-teman anggota penelitian, maka penelitian ini diupayakan pelaksanaannya dalam tiga siklus. 
Secara umum, dari siklus-1 ke siklus-2 ke siklus-3 akan dilakukan tindakan pada kemampuan guru menggunakan alat peraga, yang meliputi intensitas penggunaan alat peraga, dari rendah, sedang dan tinggi, dapat juga dikatakan bahwa pada siklus pertama, dengan tingkat penggunaan alat peraga yang belum memadai berarti tingkat abstraksi materi pelajaran masih sangat tinggi, kemudian sedang dan siklus terakhir dengan upaya tingkat abstraksinya yang rendah.

Lebih jauh tindakan akan dilakukan pada daya kreatifitas guru dalam kemampuan menggunakan, mendesain, memodifikasi, bahkan menciptakan alat peraga matematika.

\section{HASIL DAN PEMBAHASAN}

Berikut merupakan bahan-bahan yang digunakan membuat beberapa alat peraga yaitu tripleks, gergaji, jangkar, lem kayu, lem kertas, gunting, busur derajat, pensil warna, spidol warna, cat, cutter, mistar, kertas karton, kertas berwarna, dan gurinda (alat pemotong). Adapun alat peraga yang dibuat adalah alat peraga untuk bangun datar dan alat peraga untuk bangun ruang. Bangun Datar

Tripleks dipotong berdasarkan bangun-bangun datar (segitiga, segiempat, segilima, segi enam dan lingkaran). Setiap bangun datar tersebut dipotong atas beberapa bagian hal ini diperlukan untuk menjelaskan tentang konsep luas dari setiap bangun tersebut.

\section{Bangun Ruang}

Untuk bangun ruang sisi datar tripleks dipotong berdasarkan sisi bangun ruang bidang datar (kubus, balok, prisma, dan limas). Untuk bangun ruang sisi lengkung tripleks dipotong dan kertas digunting berdasarkan bangun ruang sisi lengkung (tabung, kerucut, dan bola). Hal ini diperlukan untuk menjelaskan tentang konsep luas penampang dan volume bangun ruang tersebut.

\section{Pelaksanaan Penelitian}

Pada pertemuan pertama diadakan tes awal untuk mengetahui kemampuan dasar siswa pada materi geometri tentang bangun datar dan bangun ruang. Selanjutnya pada pertemuan kedua penulis menjelaskan secara singkat tentang pengertian bangun-bangun datar, penulis mengelompokkan siswa atas delapan kelompok yang setiap kelompok tediri dari dua siswa. 
Penulis membagikan LKS setiap kelompok yang isinya tentang bangunbangun datar. Penulis membimbing siswa dalam menyelesaikan soal-soal dalam LKS. Penulis bersama siswa menyimpulkan konsep-konsep luas bangun datar. Penulis membagikan kertas untuk mengetahui tanggapan siswa terhadap proses pembelajaran.

Pada pertemuan ketiga penulis menjelaskan secara singkat tentang bangun-bangun ruang sisi datar. Penulis membagikan LKS kepada setiap kelompok yang isinya tentang bangun-bangun ruang sisi datar. Penulis membimbing siswa untuk menyelesaikan menyelesaikan soal-soal dalam LKS. Penulis bersama siswa menyimpulkan tentang volume bangun ruang sisi datar.

\section{Hasil Penelitian}

Berdasarkan data dari lapangan (data siswa kelas IX SMP Negeri 26 Makassar) dapat dilihat pada tabel berikut:

Tabel 1. Statistik Nilai Tes Awal Siswa kelas IX SMP Negeri 26 Makassar

\begin{tabular}{ccc}
\hline No & Statistik & Nilai \\
\hline 1 & Responden & 16,00 \\
2 & Skor Ideal & 10,00 \\
3 & Skor Tertinggi & 7,00 \\
4 & Skor Terendah & 3,00 \\
5 & Jangkauan & 4.00 \\
6 & Rata-rata & 5,00 \\
7 & Median & 5,05 \\
8 & Modus & 6,00 \\
9 & Standar Deviasi & 1,03 \\
10 & Variansi & 1,07 \\
\hline
\end{tabular}

Berdasarkan nilai-nilai pada tabel 1 maka yang memperoleh nilai terendah sebanyak satu orang, banyaknya siswa yang memperoleh nilai tertinggi sebanyak satu orang. Yang memperoleh nilai enam sebanyak empat orang hal ini menunjukkan bahwa sebaran data berdistribusi normal. 
Tabel 2. Statistik Nilai Siklus 1 Siswa kelas IX SMP Negeri 26 Makassar

\begin{tabular}{ccc}
\hline No & Statistik & Nilai \\
\hline 1 & Responden & 16,00 \\
2 & Skor Ideal & 10,00 \\
3 & Skor Tertinggi & 8,00 \\
4 & Skor Terendah & 5,00 \\
5 & Jangkauan & 3,00 \\
6 & Rata-rata & 6,19 \\
7 & Median & 6,00 \\
8 & Modus & 5,00 dan 6,00 \\
9 & Standar Deviasi & 1,17 \\
10 & Variansi & 1,36 \\
\hline
\end{tabular}

Berdasarkan nilai-nilai pada tabel 2 maka yang memperoleh nilai terendah sebanyak lima orang, banyaknya siswa yang memperoleh nilai tertinggi sebanyak satu orang. Yang memperoleh nilai lima dan enam sebanyak lima orang hal ini menunjukkan bahwa sebaran data berdistribusi normal.

Tabel 3. Statistik Nilai Siklus 2 Siswa kelas IX SMP Negeri 26 Makassar

\begin{tabular}{ccc}
\hline No & Statistik & Nilai \\
\hline 1 & Responden & 16,00 \\
2 & Skor Ideal & 10,00 \\
3 & Skor Tertinggi & 9,00 \\
4 & Skor Terendah & 6,00 \\
5 & Jangkauan & 3,00 \\
6 & Rata-rata & 7,50 \\
7 & Median & 7.10 \\
8 & Modus & 7,00 \\
9 & Standar Deviasi & 0,89 \\
10 & Variansi & 0,80 \\
\hline
\end{tabular}

Berdasarkan nilai-nilai pada tabel 3 maka yang memperoleh nilai terendah sebanyak enam orang, banyaknya siswa yang memperoleh nilai tertinggi sebanyak satu orang. Yang memperoleh nilai tujuh sebanyak enam orang hal ini menunjukkan bahwa sebaran data berdistribusi normal. 
Tabel 4. Statistik Nilai Siklus 3 Siswa kelas IX SMP Negeri 26 Makassar

\begin{tabular}{ccc}
\hline No & Statistik & Nilai \\
\hline 1 & Responden & 16,00 \\
2 & Skor Ideal & 10,00 \\
3 & Skor Tertinggi & 10,00 \\
4 & Skor Terendah & 7,00 \\
5 & Jangkauan & 3.00 \\
6 & Rata-rata & 8,50 \\
7 & Median & 8,20 \\
8 & Modus & 8,00 \\
9 & Standar Deviasi & 0,82 \\
10 & Variansi & 0,67 \\
\hline
\end{tabular}

Berdasarkan nilai-nilai pada tabel 4 maka yang memperoleh nilai terendah sebanyak satu orang, banyaknya siswa yang memperoleh nilai tertinggi sebanyak dua orang. Yang memperoleh nilai delapan sebanyak tujuh orang hal ini menunjukkan bahwa sebaran data berdistribusi normal. Berdasarkan nilai rata-rata dan nilai simpangan baku yang terlihat pada setiap tabel terjadi peningkatan yaitu 5,000 $<6,1875<7,5000<8,5000$, dan 1,328; 1,$16726 ; 0,89443 ; 0,81650$.

Terjadinya peningkatan skor rata dari tes awal sampai ke tes siklus ke tiga ini disebabkan karena ada perlakuan peneliti yang dilakukan dalam proses pembelajaran yaitu sebelum dilakukan penelitian diadakan tes awal selanjutnya pada siklus 1 peneliti mengadakan penyampaian tentang materi ajar (materi pendahuluan) yaitu materi tentang luas lingkaran dan luas persegi panjang (rumus-rumus). Selanjutnya siswa dikelompokkan menjadi delapan kelompok yang terdiri dari dua orang siswa. Setiap kelompok diberikan LKS yang isinya beberapa tabung yang ukurannya berbeda untuk setiap kelompok penulis mengarahkan atau membimbing siswa untuk mengukur dari setiap tabung yang ditugaskannya. Dari hasil pengukuran itu siswa menyimpulkan atau menulis rumus luas penampang tabung dan rumus volume tabung.

Berdasaran pengamatan penulis maka keaktifan siswa dalam proses pembelajaran masih tergolong rendah hal ini disebabkan karena mereka tidak menghafal rumus luas lingkaran dan rumus persegi panjang serta rumus penampang dan volume prisma. 
Pada siklus 2 penulis lebih menekankan pada konsep tentang tabung melalui alat peraga sehingga siswa terlihat antusias memperhatikan pelajaran.

Pada siklus 3 penulis menanyakan terlebih dahulu tentang luas juring dan volume limas. Sehingga siswa lebih mudah memahami tentang konsep kerujut (luas penampang dan volume). Selain aktifitas siswa yang diuraikan di atas penilis juga membagikan kertas kepada setiap siswa untuk menulis tanggapan mengenai model pembelajaran yang dilakukan oleh penulis dan pada umumnya respons siswa positif.

\section{SIMPULAN}

Pembelajaran dengan menggunakan alat peraga dengan intensitas tinggi ternyata dapat dipicu peningkatan hasil belajar matematika siswa,ha tersebut dapat ditandai dengan meningkatnya hasil belajar matematika siswa yaitu nilai rata-rata yang dicapai siswa pada awal siklus 1 kategori rendah $(5,00)$ sedangkan pada akhir siklus 1 nilai rata-rata siswa dalam kategori sedang $(6,19)$, sedangkan pada akhir siklus 2 nilai rata-rata dalam kategori tinggi $(7,50)$, dan pada akhir siklus 3 nilai rata-rata dalam kategori sangat tinggi $(8,00)$. Keterlibatan guru SMP dalam hal ini SMP Negeri 26 Makassar dan Dosen LPTK (Jurusan Matematika FMIPA UNM Makassar) sebagai mitra kerja dalam penelitian tingkat ini, menjadi motivasi bagi mereka untuk meningkatkan kemampuan profesinya, baik sebagai guru maupun sebagai peneliti dalam bidang kependidikan. Dengan adanya kerja sama denga pihak LPTK selama setahun, akan berimplikasi pada kebiasaan guru mitra untuk dapat mengembangkan sendiri metode pembelajaran dengan menggunakan alat peraga ataupun mengembangkan metode lainnya. Mereka dapat lebih terlatih untuk berpikir, bersikap, dan bertindak mandiri dalam melaksanakan tugas. Demikian pula, kebiasaaan bermitra dengan pihak LPTK, akan membangun suasana kerja yang kooperatif, dan dapat ditindak lanjuti pada masa-masa mendatang. Berkaitan dengan alat pengajaran matematika, dengan kerja sama pihak sekolah maka pihak LPTK lebih mengetahui kondisi riil yang terjadi pada guru mitra dan kebutuhan-kebutuhan siswa di lapangan, hal ini bermanfaat untuk mengevaluasi kinerja tim dosen di LPTK yang mendalami masalah-masalah alat pengajaran. Dari hasil penelitian ini terlihat, bahwa dengan menggunakan alat peraga matematika pada hampir semua pokok bahasan, dapat mengurangi tingkat abstraksi materi pelajaran, dapat membantu siswa untuk mengembangkan kemamapuan berpikir mereka sesuai dengan tingkat perkembangan intelektual. Dengan demikian hasil 
belajar matematika siswa pada pokok bahasan geometri dapat ditingkatkan melalui penggunaan alat peraga.

\section{DAFTAR PUSTAKA}

Achmad Arifin. 1991. Segi Kreatifitas dan Kemandirian dalam Proses Belajar Matematika. Makalah FMIPA ITB. Bandung.

Bole, Brian. 1982. Mathematical Activities A Resource Book for Teacher. Cambridge University Press London.

Barnes, M., Clark, D. dan Stephens, M. 1996. The Impact of External Assesment on Teaching Practice: Contraints on Change in the Classroom. In P. C. Clarkson (Ed). Technology in Mathematics Education. Melbourne: The University of Melbourne.

Cadwell Y. H. 1970. Topics in Recreational Mahematics. Cambridge University Press London.

Cook. 1991. Ethical Implication. Research Methods in Social Relation. Edited by Charles Judd, Eliot Smith and Louise Kidder, $6^{\text {th }}$ edition. In H. Connole (Ed). Research Method 1: Underdale, South Australia: The University of South Australia.

Dole, S., Cooper, T., Bleicher, R., Nisbet, S. and Warren, E. 1996. Collaborative Team Writing of Assesment Task ask Professional Development. In P. C. Clarkson (Ed.). Technology in Mathematics Education. Melbourne : The University of Melbourne.

Galbrait, P., Pemberton. M. and Hainest, c. 1996. Testing to a Purpose : Assessing the mathematimalcal Knowledge of Entering Undergraduate. in P .C. Clarkson (Ed). Technology in Mathematics Education. Melbourne: The University of Melbourne.

Hudoyo, Herman. 1990. Strategi Mengajar Belajar Matematika. IKIP Malang.

Kemmis, s. \& Carr w. 1990 Becoming Critical: Education, Knowledge and Action Research. Melbourne: Deakun University. 